\title{
Description of Lutzomyia (Pifanomyia) robusta n. sp. (Diptera, Psychodidae, Phlebotominae) from Peruvian Equadorean interandean areas
}

\author{
Eunice A. Bianchi Galati, Abraham G. Cáceres, François Le Pont \\ Department of Epidemiology, School of Public Health, University of S. Paulo - Brazil (E.A.B.G.) \\ Instituto de Investigación Epidemiologica "Dr. Hugo Lumbreras Cruz", Instituto Nacional de Salud - Peru \\ (A.G.C.) ORSTOM - France (F.L.P.)
}

\begin{abstract}
Description of Lutzomyia robusta, $n$. sp. (Diptera, Psychodidae, Phlebotominae) from interandean areas of Peru and Equador. Lutzomyia robusta, $n$. sp., probable vector of human bartonellosis and cutaneous leishmaniasis, is described and illustrated. This species presents strong affinity with $L$. serrana (Damasceno \& Arouck, 1949) but they can be dlstinguished by variance analysis of four male characteristics and onty one female characteristic. In the variance analysis, populations of $L$. serrana, of Amazonian areas of Brazil, Peru and Bolivia, the coast of Equador and other areas of Brazil were studjed. The synonymy of Lutzomyia guayasi (Rodriguez) and L. serrana was corroborated.
\end{abstract}

Psychodidae, classification. Ecology, vectors.

Captures of sand flies carried out in the Region Nor-Oriental del Marañón, Peru, between $5^{\circ} 3^{\prime} \mathrm{SL}$ - 78 53' WL and 6 $6^{\circ} 5^{\prime} 30^{\prime \prime} \mathrm{SL}-78^{\circ} 30^{\prime} 29^{\prime \prime} \mathrm{WL}$, in the provinces of San Ignacio (interandean valley of Chinchipe), Jaen (interandean valley of Chamaya and Chinchipe) and Utcubamba (right bank of River Marañon), during the period 1987 - 1992, motivated by the occurrence of an outbreak of human bartonellosis, showed the presence of five new species: two, of the subgenus Helcocyrtomyia Barretto (Galati \& Cáceres ${ }^{3}, 1994$ ) and three, of the subgenus Pifanomyia Ortiz \& Scorza; two of wich latter have already been described (Galati et $\mathrm{al}^{4}, 1995$ ) and the third of wich, L. robusta, n, sp., is the object of the present study. This species, in both sexes, is very close to $L$. serrana (Damasceno \& Arouck, 1949), the differences between them being more quantitative than qualitative; hence the two species have been confused.

In the mentioned areas, in intradomiciliary captures, with light CDC trap, $L$. robusta, $\mathbf{n}$. sp. showed the greatest density and in the peridomicile, with human bait, was one of the most prevalent; this behaviour suggests its involvement in the transmission of the parasitosis. Using the same capture techniques this new species was the most frequent in the Equador area, near the border of Peru, in the Amazonian province of ZamoraChinchipe, where cases of human bartonellosis were also identificated and which is considered a cutaneous leishmaniasis endemic zone (Le Pont et al. 5,1994$)$.

Rodriguez ${ }^{6}$ (1956) describes the male and female of Phlebotomus (Brumptomyia) guayasi from the coast of Equador, which has been regarded as identical with $L$, serrana by Fairchild \& Hertig $^{2}$ (1961).

Because of the great similarity between the two species and the probable implication of this new taxon in the transmission of the above mentioned parasitoses, it is necessary to clarify its taxonomic status. With this purpose in view, some morpholog- 
ical characteristics were submitted to variance analysis, by means of a comparison of populations of Lutzomyia robusta, n. sp. of the interandean areas with those of the Lutzomyia serrana of the areatype (Amazonian Brazilian region), as well as with the Peruvian and Bolivian Amazonian areas and of other areas of Brazil and of the coast of Equador.

\section{Material and Method}

For the variance analysis, 8 male characteristics were observed: length: flagellomere $I$, labrum-epipharynx, hind tibia, $\mathbf{R}_{5}$, genital ductus; width of the wing and paramere and ratio between length and width of paramere apical area (setal area) of two populations of Lutzomyia robusta, n.sp. of the interandean areas: PeruRegion Nor-Oriental (NO) and Equador Zamora-Chinchipe Region (ZC) and of nine populations of $L$. serrana (except for hind tibia of the areas: Amazonian: Peru Loreto/Madre de Dios (PA), Bolivia - Pando (BO) and Brazil Pará/Maranhão (PM), Rondônia (RO), Acre (AC), Mato Grosso (MT); Atlantic - Brazil Bahia/Espírito Santo/Rio de Janeiro (AT) and inland areas of Brazil Minas Gerais (MG) and the coast of Equador (EC). For the hind tibia, the following areas were not included: $\mathrm{BO}, \mathrm{AC}, \mathrm{RO}$, because in the specimens examined it was missing. For females, 7 characteristics were observed: length: flagellomere I, labrumepipharynx, $R_{5}$, fore, mid and hind tibiae and wing width, in the populations of $L$. robusta of NO, ZC and only four populations of $L$. serrana: BO, MG, MT, EC.

Sclerotized characteristics, the least subject to measurement variations, were selected for observation only.

The program used was prepared by J. L. F. dos Santos, professor of Department of Epidemiology, of the Faculdade de Saúde Pública, of the Universidade de São Paulo. The confidence interval was calculated by Gabriel's formula (Sokal \& Rolhff ${ }^{8}, 1981$ ), which is:

Confidence interval $=\mathrm{y}_{1} \pm \sqrt{\frac{1}{2}} \mathrm{~m}\left[\mathrm{k}^{*}, \mathrm{v}\right] \mathrm{S}_{\mathrm{yi}}$

where: $y i$ is the average values of each characteristic; $m$ the critical value (alpha $=0.05$ ) obtained from table 21 of "Studentized range" Rolhf \& Sokal $^{7}, 1981$ ); $S y_{i}$ the standard error; $k^{*}$ the $n^{\circ}$ of places of the origir and the $v$ degrees of freedom within of the treatment.

\section{Results}

The greatest values and the overlapping of the all confidence intervals (CI) can be observed with regard to all eight characteristics submitted to variance analysis for the males of the interandean populations $\mathrm{ZC}$ and $\mathrm{NO}$ (Fig. 27).

The overlapping of the $\mathrm{CI}$ occurs with regard to the populations of the Amazonian region: PA, $\mathrm{BO}, \mathrm{AC}, \mathrm{PM}, \mathrm{RO}, \mathrm{MT}$ and those from the Atlantic area (AT) and the coast of Equador (EC).

The MG population presents the CI values closest to those of $\mathrm{ZC}$ and NO, with overlapping of the labrum-epipharynx length and wing width of the males.

By means of the $\mathrm{R}_{5}$ length $\mathrm{CI}$ three population groups can be distinguished: the first covering the Amazonian and Atlantic areas and of the coast of Equador; the second $M G$ and the third of the interandean region.

Besides $\mathbf{R}_{\mathbf{5}}$ length, the two interandean populations are distinguished from the others by their hind tibia, paramere width and ratio between length and width of the apical part of the paramere.

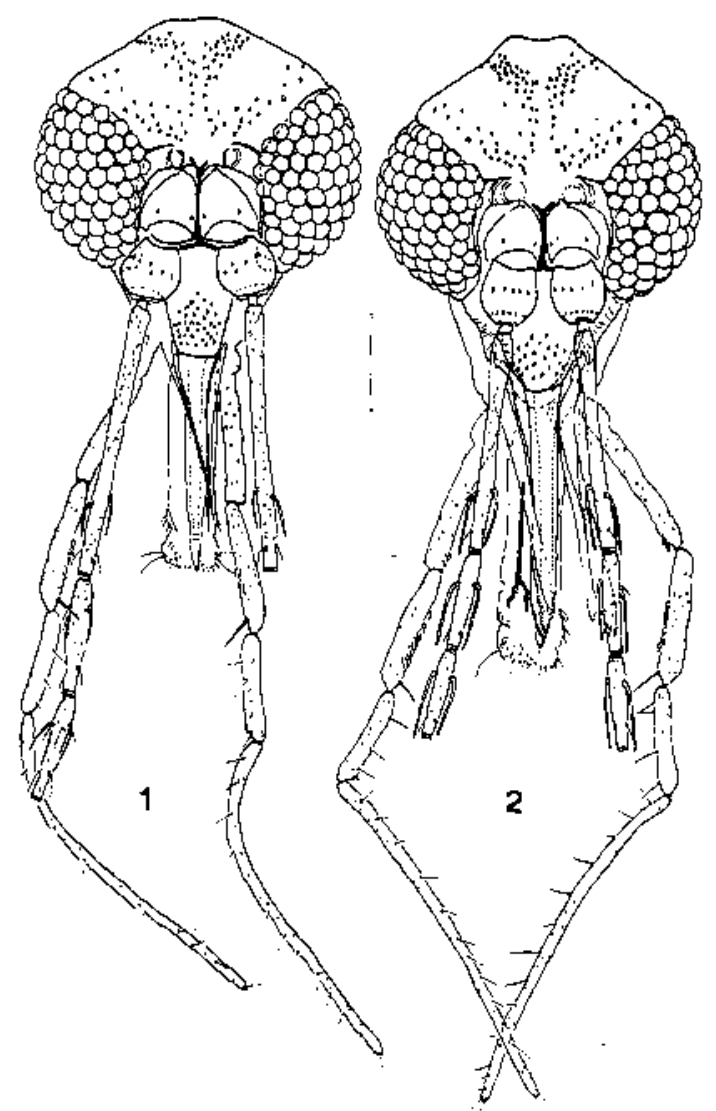

Figures 1 e 2 - Lutzomyia robusta, n. sp. 1, head $\checkmark ; 2$, head $\bigcirc$. Scale: $100 \mu \mathrm{m}$. 
The $\mathrm{Cl}$ of the females (Fig. 28) of the $\mathrm{ZC}$ and NO populations always overlap and present the greatest values; nevertheless, except for $\mathrm{R}_{5}$, they cannot be distinguished from the $\mathrm{CI}$ of the other populations.

Lutzomyia (Pifanomyia) robusta $\mathrm{n}$. sp. (Figs. 1 - 25)

Lutzomyia serrana, partim; Alexander et $\mathrm{al}^{1}$., 1992: 128 .

Lutzomyia serrana; Le Pont et a1 ${ }^{5} ., 1994:$ $43,46-48$.

Male. Holotype. Length $c a .2 .4 \mathrm{~mm}$ (paratypes: $2.5 \pm 0.2 \mathrm{~mm}$; $\mathrm{n}=10$ ). Coloration clear brown, more accentuated on head and mesonotum.

Head (Fig. 1). Ratio length/width 1.10 (1.10 \pm $0.04)$. Ratio between the lengths: clypeus/head $0.33(0.33 \pm 0.01)$; AIII/LE $1.32(1.26 \pm 0.06)$; eyes/head $0.57(0.55 \pm 0.03)$. Palpal formula: 1.4.2.3.5 (1.4.2.3.5; $\mathrm{n}=7$ and 1.4(2.3).5; $\mathrm{n}=3$ ). Palpomere III, as in Figure 6. Antenna: ascoidal formula: AIII-AXIII 2. AXIV-AXV 1. AXVI 0; AIV e AV, as in Figures 3 and 4, respectively; rosette sensillae absent in AXI-AXIII and present in AXIV-AXVI (Fig. 5). Cibarium, as in Figure 7. Measurements, Table 1.

Thorax. Pleura with $3(2$ - 4) proepimeral (lower anepisternal) and $11-12(6-10)$ upper anepisternal setae. Measurements, Table 2. Wing, as in Figure 17.

Abdomen. Tergites V-VII with tergal papillae. Stemite II (Fig. 18) with 8 (8-17) setae. Terminalia (Fig. 23): Style $108 \mu \mathrm{m}(106 \pm 4 \mu \mathrm{m})$ with subterminal seta, 2 strong spines: the apical and the subapical external upper spine and 1 internal spine, atrophied and situated near the base of the structure (this spine has a variable length and width). Coxite $178 \mu \mathrm{m}$ (181 $\pm 9 \mu \mathrm{m}$ ) long, with basal sclerotized ridge and a tuff with 5 upturned curved setae, 4 of these are implanted in a single row and 1 situated out of line (Fig. 25). Paramere as in Figures 24 and 26. Aedeagus conical. Lateral lobe $227 \mu \mathrm{m}(226 \pm 13 \mu \mathrm{m})$ long, with round top. Cercus, as Figured. Genital pump $98 \mu \mathrm{m}$ (102 \pm $7.6 \mu \mathrm{m}$ ) long and ducts striated on the apical area, $388 \mu \mathrm{m}(374 \pm 32 \mu \mathrm{m})$ long, nearly $3.96(3.66 \pm$ 0.20 ) $x$ length of pump (Fig. 21).

Female $(n=10)$. Coloration, as in the male. Length, nearly $2.53 \pm 0.11 \mathrm{~mm}$.

Head (Fig. 2). Ratio length/width $1.11 \pm 0.02$. Ratio between the lengths: clypeus/head $0.337 \pm$ 0.006 ; eye/head $0.53 \pm 0.02$. AIII/LE $0.94 \pm 0.03$. Palpal formula 1.4.2.3.5. Palpomeres II and III, as in Figures 9 and 10. Antenna: AIV and AV, as in Figures 13 and 14; Ascoidal formula AIII-AXV 2. AXVI 0 ; rosette sensillae absent in the AXI-AXIII and present in the AXIV-XVI (Fig. 15). Cibarium (Fig. 8) with 4 equidistant horizontal teeth; 12-22 vertical teeth, distributed in a transversal irregular row and in lateral group; 3-4 little lateral teeth in each side; sclerotized arch complete. Pharynx, with apical area wrinkled and with atrophied teeth. Hipopharynx (Fig. 12) with 12-15 apicolateral teeth. Maxilla (Fig. 11) with 4-6 external teeth, in a single row and 16-22 internal teeth.

Thorax. 2-4 proepimeral (lower anepisternal) and 6-14 upper anepisternal setae. Wing as shown (Fig. 16). Measurements, Table 2.

Abdomen. Stemite II (Fig. 19) with 5-10 setae. Terminalia (Fig. 20): Tergite VIII with 1-6 setae on each side; cercus as figured. Espermathecae (Fig. 22) vesiculous, striated and with terminal annulus $(9.8 \pm 1.0 \mu \mathrm{m}$ long and $18.7 \pm 2.4 \mu \mathrm{m}$ in widht), without evident transition with the individual ducts, which are predominantly smooth, but striated joint to the spermatheca; this structure measures in length $103.8 \pm 14.2 \mu \mathrm{m}$ and in width $7.5 \pm 0.4 \mu \mathrm{m}$, at the level of the joint with common duct, and $24.5 \pm 2.0 \mu \mathrm{m}$ at the level of the spermatheca; common duct smooth, $157.3 \pm 33.9 \mu \mathrm{m}$ long by $14.7 \pm 1.4 \mu \mathrm{m}$ at maximum width.

Types: Holotype $\sigma^{\prime}$. Peru, Region NorOriental del Marañón, San Ignacio, La Coipa (Barro Negro) (1500 m) (bedroom, with CDC - all night), 18/19.III.1992, (INSP). Paratypes $340^{\circ}$, 35 O. Peru, Región Nor-Oriental del Marañon, province of San Ignacio, district of La Coipa (same data as the holotype) $20^{\circ}, 1 \bigcirc$ (INSP), 3 $O^{\prime} ; 10$ (FSP), $1 O^{\prime \prime}$ (ORSTOM); ibidem (Estrella Divina) $(1500 \mathrm{~m})$ (bedroom, with CDC - all night), 14/15.III.1992, $1 \sigma^{\top} 1 \bigcirc$ (FSP); ibidem (Las Cabazas) $(1200 \mathrm{~m})$ (bedroom, with CDC - all night), 17/18.III.1992, $2 \sigma^{7}$ (INSP); ibidem (Loma del Rey) $(1500 \mathrm{~m}$ ) (domicile, with cigarette smoke, aspirator and manual lantern), 16.III.1992, 2 Q (INSP), 1 O", 1 (FSP), 3 Q (ORSTOM), 2 (CPRR); ibidem (Pacaipite) $(1460 \mathrm{~m})$ (bedroom, with CDC all night), 16/17.III.1992, 1 (INSP) ibidem (peridomicile, with Shannon trap, 19:00 - 22:00 hours), 16.III.1992, 2 Q (FSP); ibidem (Vira-Vira) (1560 m) (bedroom, with CDC - all night), 15/16.III.1992, 2 (INSP), $30^{\circ} ; 2$ (FSP); district of San José de Lourdes (El Milagro) (1180 m) (rock crevice and tree root with cigarette smoke and manual aspirator), 14.II.1987, $1 \sigma^{\circ} ; 1$ O (INSP), $10^{\circ}, 1 \bigcirc$ (FSP), $2 \sigma^{\prime}$ (ORSTOM), 1 $\sigma$ (CPRR); ibidem $(1260 \mathrm{~m})$ (bedroom, with CDC - all night), 19/20.IIl.1992, 2 O (INSP), 1 ○ (FSP), 4 (ORSTOM), 3 (CPRR); ibidem 


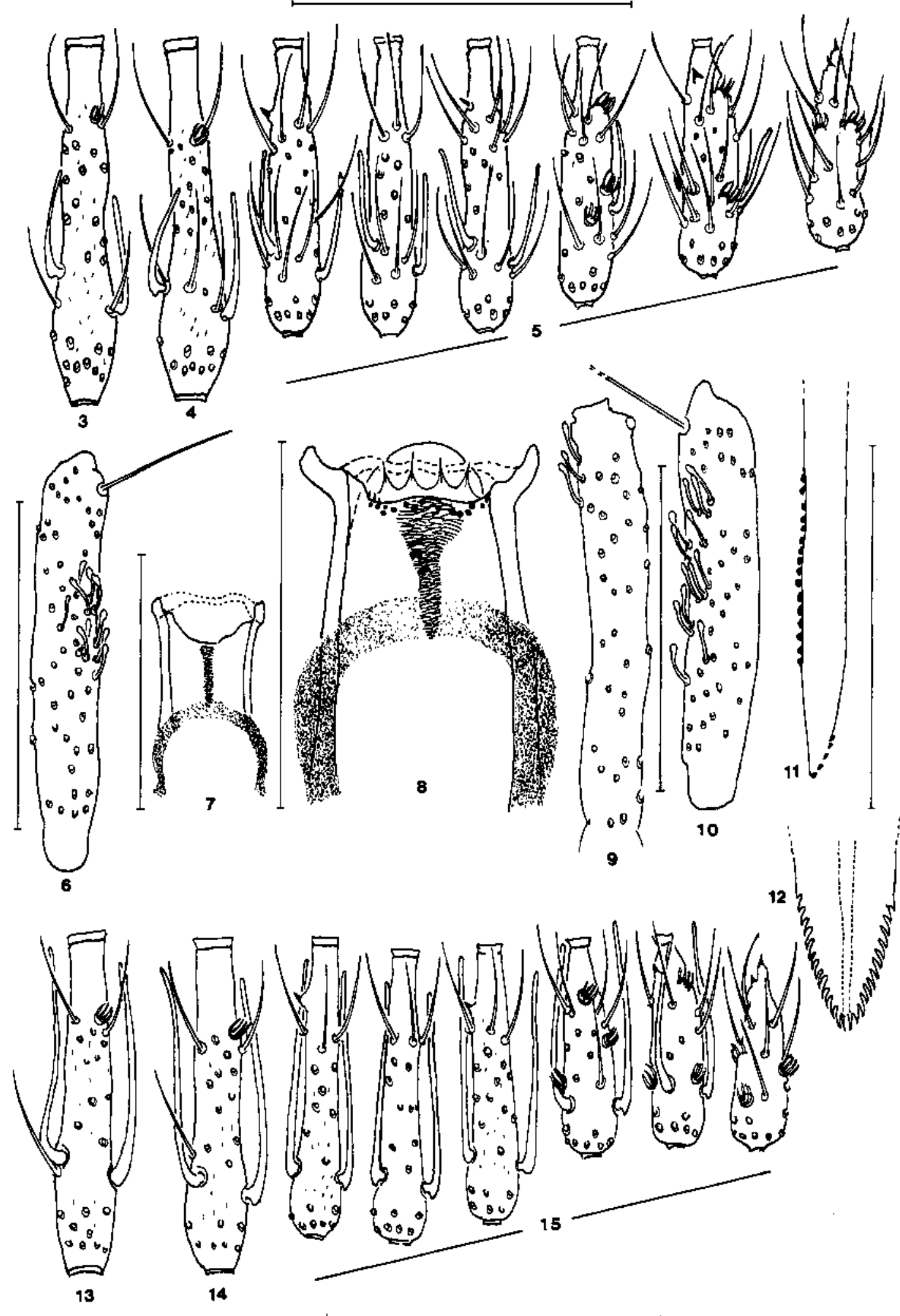

Figures 3 -15 - Lutzomyia robusta, n. sp. 3, AIV O'; 4, AV O'; 5, AXI-AXVI O'; 6, palpomere III $\sigma^{\prime} ; 7$, cibarium $O ; 8$, cibarium $Q ; 9$, paipomere II $Q ; 10$, palpomere III $Q ; 11$, maxilla $Q ; 12$, hypopharynx $Q ;$ 13, AIV O; 14 AV Q; 15 AXI-AXVI Q. Scale: $100 \mu \mathrm{m}$. 
Table 1 - Measurements $(\mu \mathrm{m})$, of the head characteristics of the holotype and paratypes of Lutzomyia robusta, n. sp.

\begin{tabular}{|c|c|c|c|c|c|}
\hline \multirow{3}{*}{ Characteristics } & \multirow{3}{*}{$\begin{array}{l}\text { Holotype } \\
\text { (male) }\end{array}$} & \multicolumn{4}{|c|}{ Paratypes } \\
\hline & & \multicolumn{2}{|c|}{ males $(n=10)$} & \multicolumn{2}{|c|}{ females $(n=10)$} \\
\hline & & $\bar{x}$ & $\mathrm{SD}$ & $\bar{x}$ & SD \\
\hline 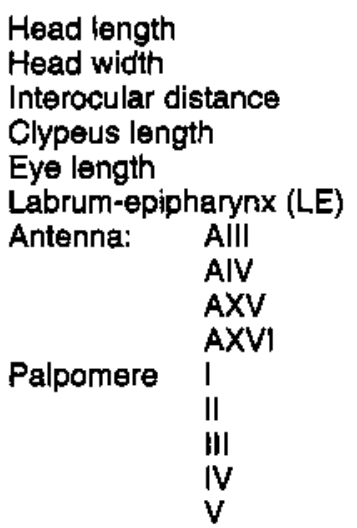 & $\begin{array}{r}340 \\
310 \\
110 \\
113 \\
195 \\
213 \\
280 \\
120 \\
75 \\
63 \\
33 \\
128 \\
130 \\
108 \\
380\end{array}$ & $\begin{array}{r}343 \\
314 \\
110 \\
115 \\
188 \\
209 \\
264 \\
118 \\
70 \\
65 \\
31 \\
128 \\
134 \\
109 \\
362\end{array}$ & $\begin{array}{r}19 \\
19 \\
3 \\
6 \\
14 \\
15 \\
24 \\
9 \\
4 \\
3 \\
4 \\
10 \\
10 \\
8 \\
22\end{array}$ & $\begin{array}{r}387 \\
350 \\
120 \\
129 \\
206 \\
272 \\
254 \\
108 \\
67 \\
57 \\
41 \\
148 \\
154 \\
125 \\
417\end{array}$ & $\begin{array}{r}11 \\
13 \\
3 \\
5 \\
5 \\
10 \\
12 \\
7 \\
5 \\
3 \\
4 \\
2 \\
8 \\
6 \\
6 \\
18\end{array}$ \\
\hline
\end{tabular}

Table 2 - Measurements $(\mu \mathrm{m})$, of the thoracic characteristics of the holotype and paratypes of Lutzomyia robusta, n. sp.

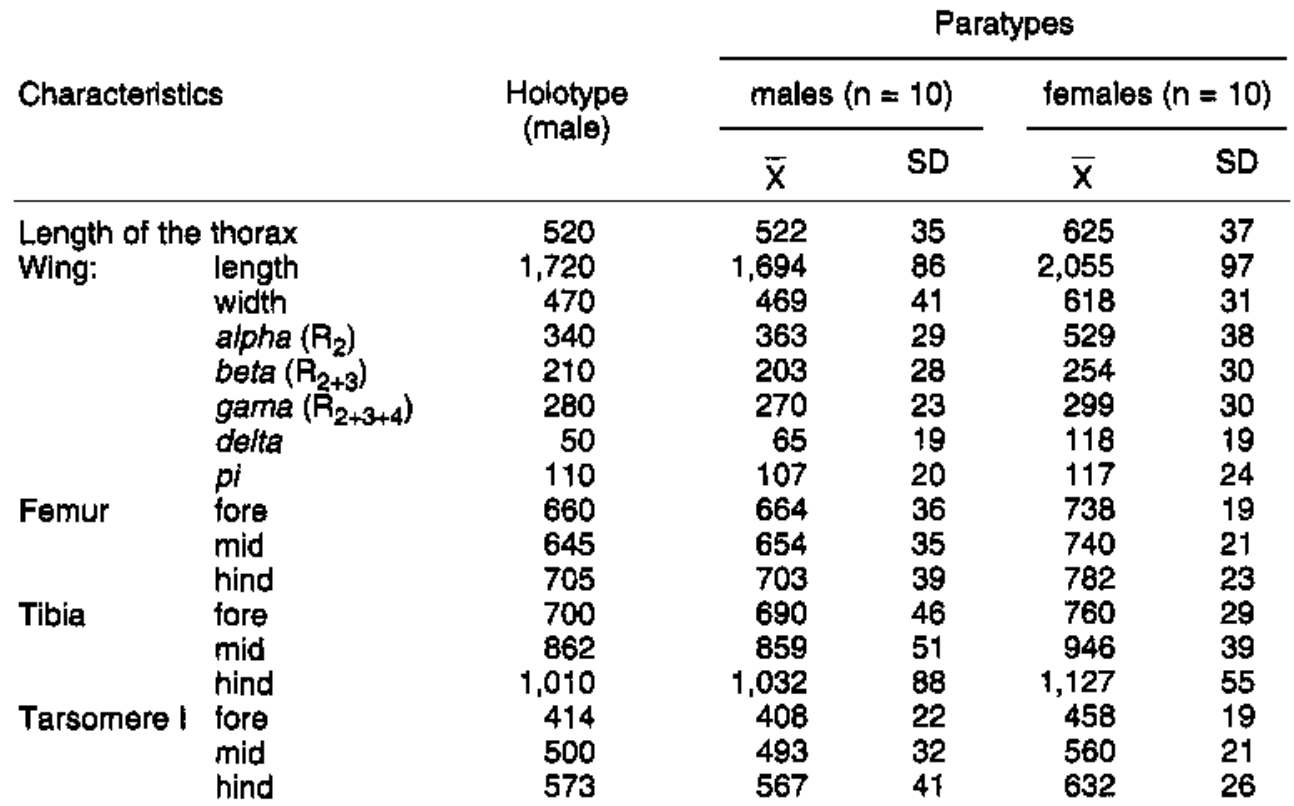

Patio: tarsomere 1/ Tarsomeres II + III + IV + V

$\begin{array}{llllll}\text { fore } & 0.70 & 0.71 & 0.01 & 0.72 & 0.02 \\ \text { mid } & 0.78 & 0.77 & 0.02 & 0.80 & 0.02 \\ \text { hind } & 0.81 & 0.83 & 0.02 & 0.85 & 0.02\end{array}$

(El Salto) $(1020 \mathrm{~m}$ ) (peridomicile, human bait, room, CDC - all night), 20/21.III.1992, $3 \sigma$ 18:30 - 19:00 hours), 20.III.1992, $30^{\circ}$ (INSP), $10^{*}, 1$ (FSP), $40^{7}$ (ORSTOM), $30^{7}$ (ORSTOM); ibidem (La Loma) $(1260 \mathrm{~m}$ ) (bed- (CPRR); province of Jaén, district of Jaén 

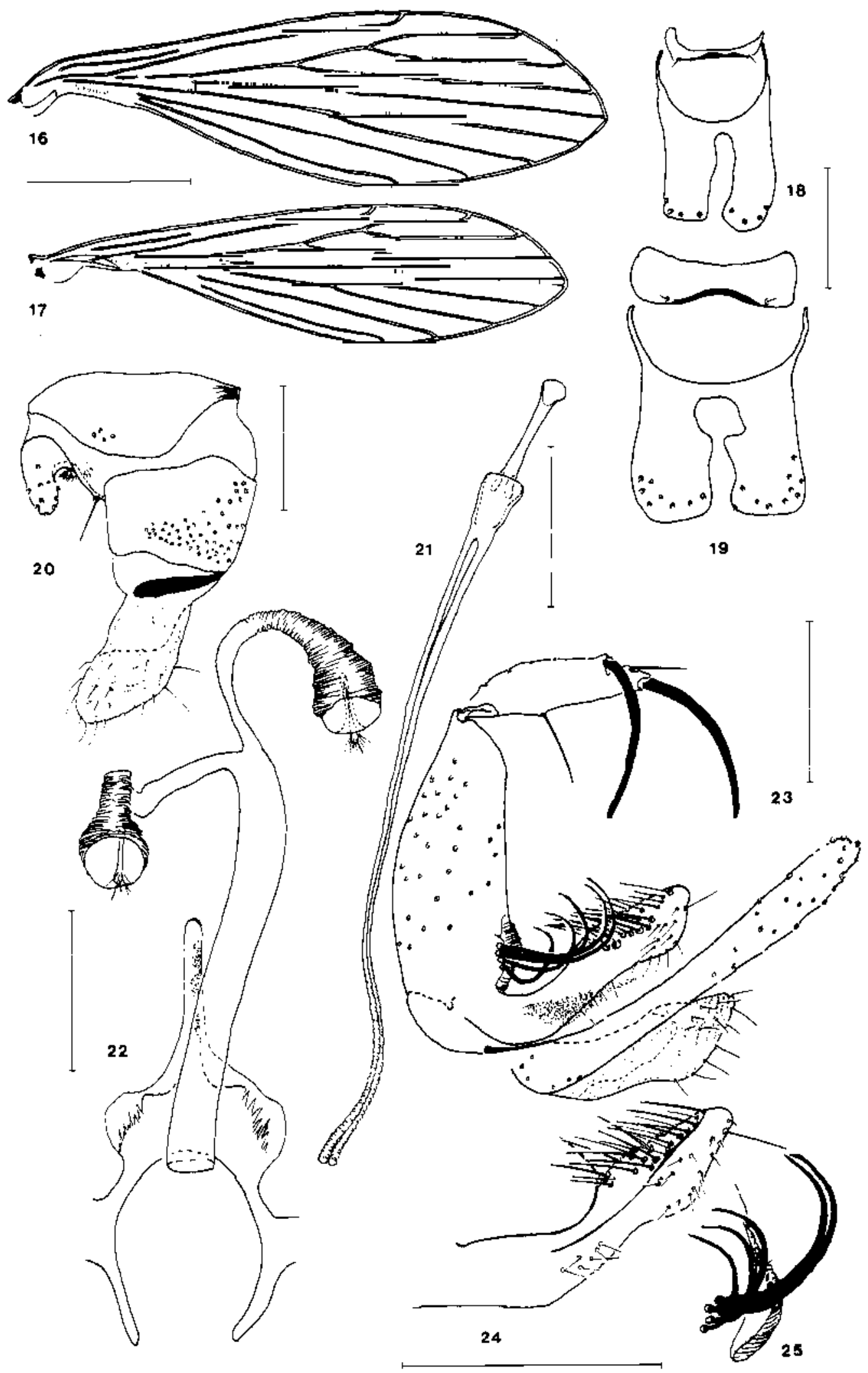

19

Figures 16-25 - Lutzomyia robusta, n. sp. 16, wing $\bigcirc ; 17$, wing $\sigma^{7} ; 18$, I and II sternites $\sigma^{\prime} ; 19$ I e li sternites $O ; 20$, terminalia $O ; 21$, genital pump and ducts $O^{\prime} ; 22$, espermathecae $Q ; 23$, terminalia $\sigma^{7} ; 24$, paramere $\sigma ; 25$, coxite setal tuff $\sigma^{\prime}$. Scales: wings $=500 \mu \mathrm{m}$; other figures, $100 \mu \mathrm{m}$. 
(Zonanga Alto) $(1330 \mathrm{~m}$ ) (peridomicile - human bait, 19:30 - 20:00 hours), 29.IX.1992, 3 Q (ORSTOM); ibidem (San Nicolas, La Chirimoya) (bedroom with cigarette smoke and manual aspirator), 29.IX.1992 1 $0^{*}, 1 \bigcirc$ (INSP); ibidem, district of Santa Rosa (Puentecillos) (1680 m) (bed- room, with CDC - 17:00 - 22:00 hours), 3.X.1992 $1 O^{\prime}$ (INSP). The specimens were all captured by A.G. Cáceres, R. Jimenéz, R. Diaz and E. León.

(CPRR) Centro de Pesquisa René Rachou, Fundação Oswaldo Cruz, Belo Horizonte, Minas Gerais, Brazil; (FSP) Faculdade de Saúde Pública,

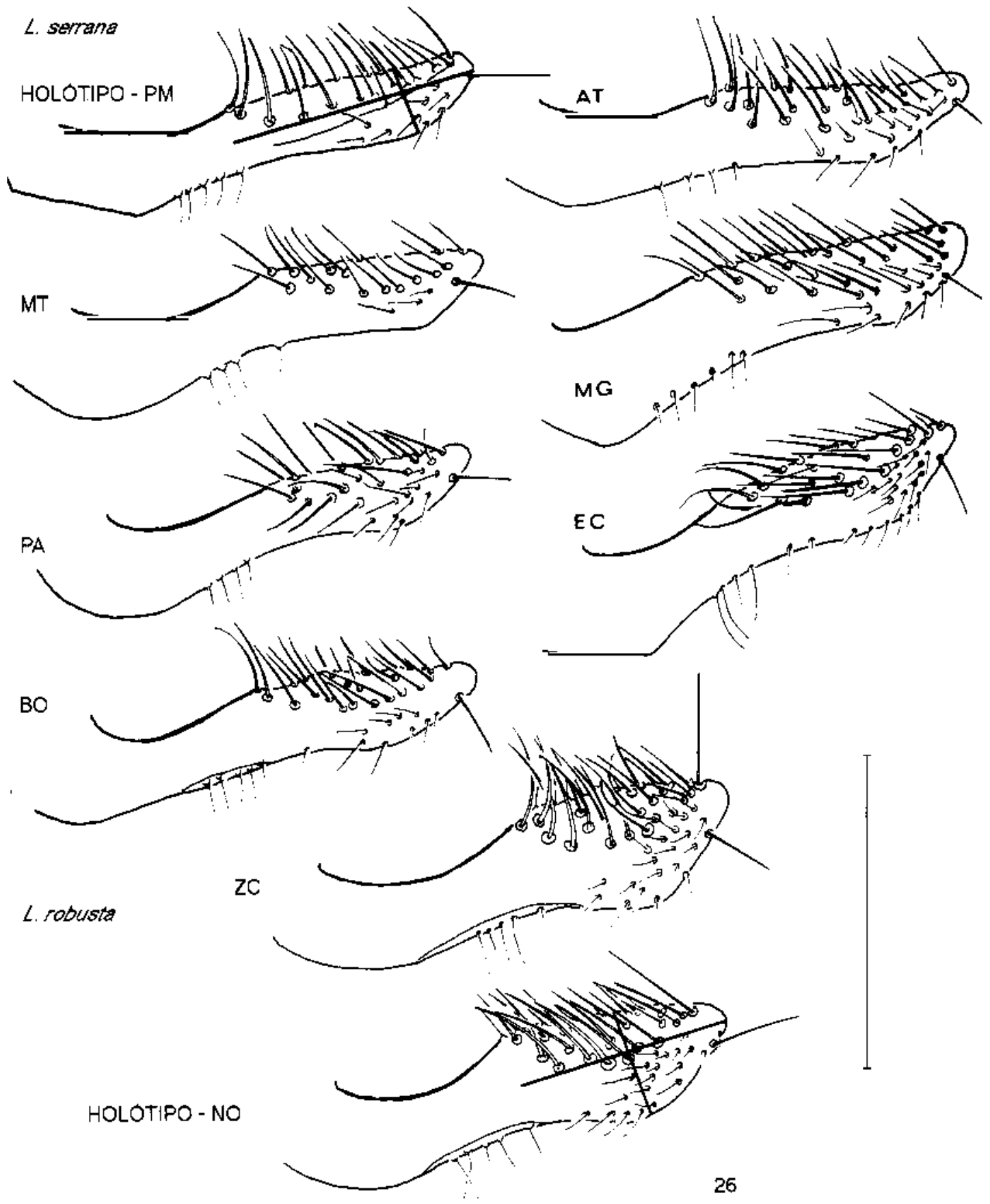

Figure 26 - Parameres of Lutzomyia serrana populations: AT, Atlantic, Brazil; BO, Bolivia-Amazonian; EC. Equador-Coast; MG, Minas Gerais, Brazil; MT, Mato Grosso, Brazil; PA, Peru-Amazonian; PM, ParáMaranhão, Brazil and Lutzomyia robusta n. sp.: NO, Region Nor-Oriental del Marañón, Peru and ZC, Zamora-Chinchipe, Equador. 
Universidade de S. Paulo, S. Paulo, Brazil; (INSP) Instituto Nacional de Salud, Lima, Peru; (ORSTOM) Centre de Bondy, Bondy, France.

\section{Comments}

Based on the eight characteristics of the males and seven of the females submitted to variance analysis, the interandean populations are similar. On the other hand, it is possible to distinguish them from all the populations of $L$. serrana studied by means four characteristics of the males: lengths of $R_{5}$ and hind tibia, width of the paramere and ratio between length and width of the apical area of the paramere (Fig. 26) and only one of the females: length of $R_{5}$.

It is possible distinguish the males of the two interandean populations of the $L$. serrana from the area-type (Amazonian) by means of the length of the AIII, labrum-epipharinx and by the wing width also.

The Mato Grosso (MT) population was included among those of the Amazonian area because the specimens were from the north of the State, which has the same ecological characteristics, as also the specimens from Pará and Maranhão (PM) which were studied together because they belong to areas characterised by similar vegetal cover.

The females of the $L$. robusta and $L$. serrana are not distinct, except as regards the $R_{5}$ length.

The population of $L$. serrana from Minas Gerais (MG) presents the confidence interval values nearest to those of $L$. robusta and at times, these are different from those of the Amazonian and Atlantic areas; hence it needs to be better evaluated, in view of possible genic flux interruption among the three $L$. serrana populations.

Based on this data, we denominate the new species of $L$. robusta, encountered in the NorOriental del Marañón region of Peru and ZamoraChinchipe, Equador, because of the larger size of the characteristics analysed, as compared to those of the $L$. serrana.

Since it was impossible to distinguished between the confidence intervals of the coastal population of the of Equador and those of the other $L$. serrana populations, as regards the various characteristics submitted to variance analysis, the synonymy of $P$. guavasi Rodriguez, as determined by Fairchild \& Hertig ${ }^{2}$ (1961), is corroborated.

Taxonomic Discussion. The serrana series of the subgenus Pifanomyia, according to Galati et al. ${ }^{4}(1995)$ is characterized, in both sexes, by presenting long palpomere $\mathrm{V}$, rosette sensilla on $\mathrm{AV}$ (except for series evansi) and the absence of the rosette sensilae on AXII and AXIII. Males with one ascoid on AXIV and AXV; style with subapical seta and three spines (the inferior external spine was lost) with internal spine situated on basal region of the structure; coxite with basal tuff constituted up to nine setae implanted directly on the surface, and lateral lobe with round top, without differentiated setae. The females present setae on tergite VIII; the spermathecae are striated and vesiculous, with terminal annulus. The species with these characteristics are: $L$. odax (Fairchild \& Hertig, 1961), L. oresbia (Fairchild \& Hertig, 1961), L. orestes (Fairchild \& Trapido, 1950), L. ottolinai (Ortiz \& Scorza, 1963), L. robusta, n. sp. e L. serrana (Damasceno \& Arouck, 1949).

The distinguishing marks of the males of serrana series can be observed from the following key:

1. Coxite tuff with straight setae .....................2 Coxite tuff with upturned curved setae ........3

2(1) Coxite tuff with 5 setae, the top of the longest of wich reaches paramere one....... $L$. oresbia Coxite tuff with 3-4 setae, the top of the longest of which almost reaches the middie of the paramere L. ottolinal

3(1) Coxite tuff with 5 setae ...............................4 Coxite tuff with 6-7 setae..................L. odax

4(3) Paramere: ratio between length and width of apical part (setal area) smaller than or equivalent to 2.0 and with evident concavity on the dorsal margin, preceding the setal area ................................. robusta, n. sp. Paramere: ratio between length and width of apical part (setal area) larger than or equivalent to 2.5 ; dorsal margin approximately straight L. serrana

The females of $L$. robusta, $\mathrm{n}$. sp. in can be distinguished from the those of $L$. oresbia because they present spermathecae with large terminal annulus, its length is about $1 / 2$ of those of the striated part. The separation of the other species was not possible, except by $R_{5}$ length, studied in the variance analysis, with regard to the $L$. serrana.

The association between the sexes of $L$. robusta, sp. n. was based on body coloration and by the simultaneous capture of males and females in the absence of other species of Pifanomyia, series serrana. 

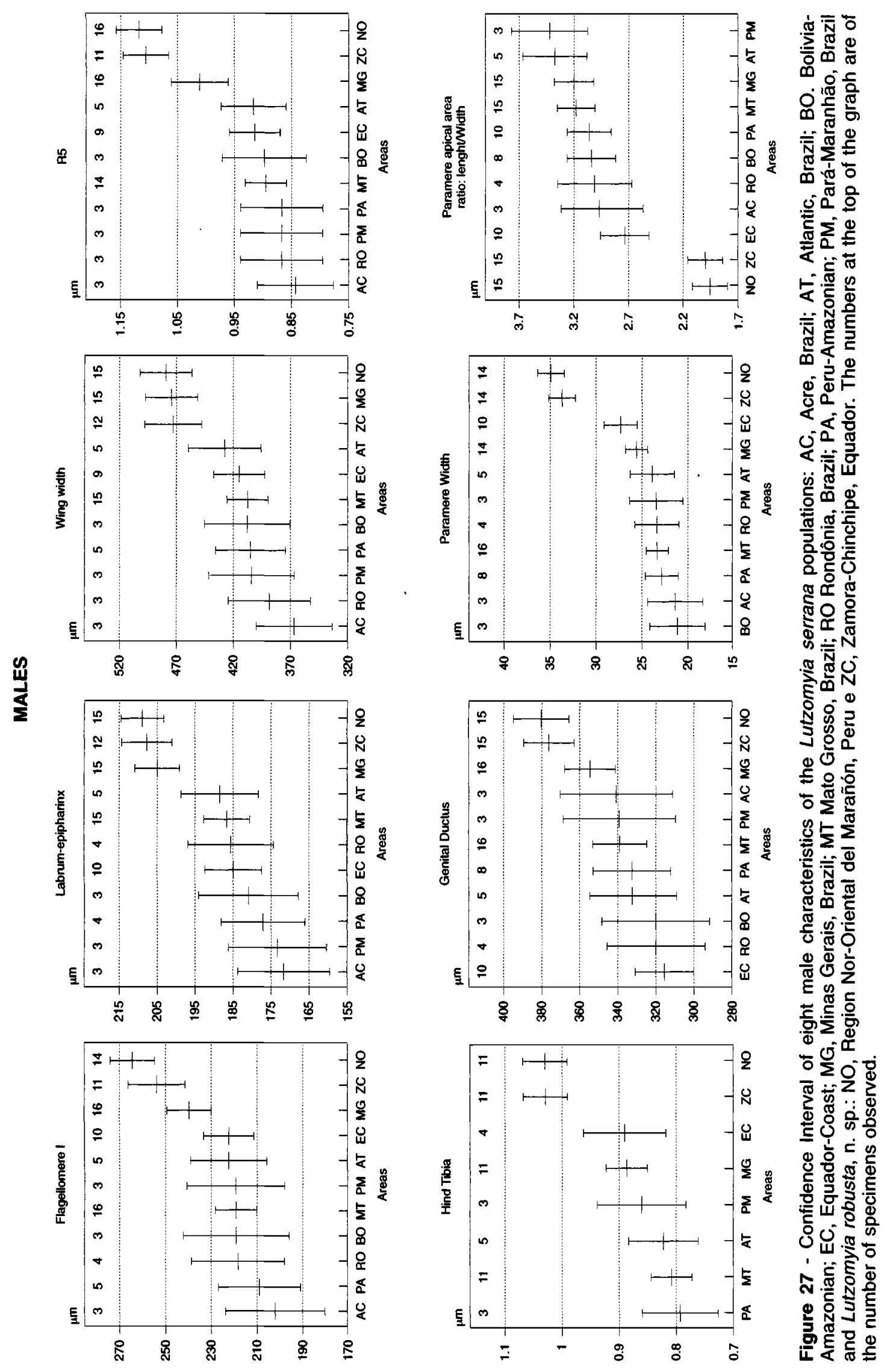

Galati, $E A B$ et al. 


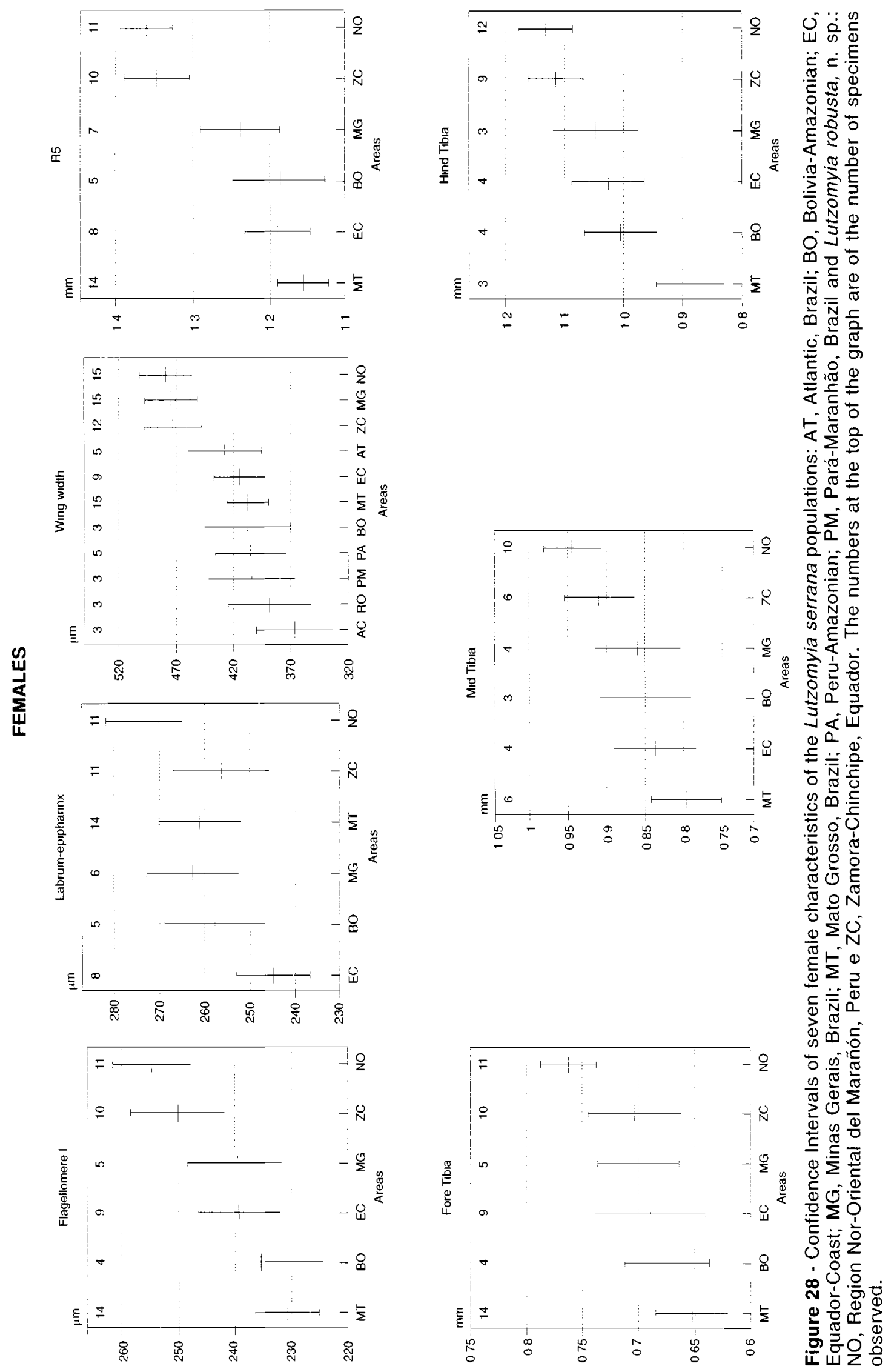




\section{Conclusions}

It was possible to distinguish $L$. robusta, $\mathrm{n}$. $\mathrm{sp}$. from the various $L$. serrana populations on the basis of four male characteristics among the eight submitted to variance analysis and only one of the female characteristics among the seven analysed.

The males of $L$, robusta, can be distinguished from those of the L. serrana by the appearance of the paramere, that in the former presents strong dorsal concavity preceding the setal area and is straigther in the latter.

The females of $L$. robusta are distinct those of the $L$. serrana as regard $\mathrm{R}_{5}$ length only.

The $L$. serrana population from Minas Gerais presents male labrum-epipharynx and $R_{5}$ length and wing width confidence intervals distinct from those of the populations of the Amazonia and Atlantic areas. Thus, further more studies are necessary for its taxonomic characterization.

The $L$. serrana population from the coast of Equador is indistinguishable from the other population of the Amazonian areas. Thus, the synoymy of $P$. guayasi with $L$. serrana is corroborated.

\section{References}

1. ALEXANDER, J.B.; TAKAOKA, H.; ESHITA, Y.; GOMEZ, E.A.; HASHIGLCHI, Y. New records of Phlebotomine sand flies (Diptera: Psychodidae) from Ecuador. Mem. Inst. Oswaldo Cruz, 88:123-30, 1992.

2. FAIRCHILD, G.B. \& HERTIG, M. Notes on the Pblebotomus of Panama (Diptera, Psychodidae). XVI. Descripitions' of a new and little-know species from Panama and Central America. Ann Entomol. Sac. Amer, 54:237-55, 1961.

3. GALATI, E.A.B. \& CÁCERES, A.G. Descrição de Lutzomyia palliditborax, sp. $\mathrm{n}$. e de Lutzomyia castanea, sp. n. do Peru e análise cladística das séries do subgênero Helcocyrtomyia Barreto (Diptera, Psychodidae). Rev. Bras. Entomol., 38: $471-88,1994$.

4. GALA, E.A.B.; CÁCERES, A.G.; IE PONT, F. Descrição de duas espécies novas de Phlebotominae (Diptera, Psychodidae) e consideraçōes sobre a

\section{Examined Materlal}

L. serrana: Brazil: Pará - Vizeu (Holotype $O^{\top}$ ) (FSP); Irituia $1 \bigcirc^{\prime}$; Maranhão - Turiaçu $1 O^{\prime}$; Acre - Cruzeiro do Sul $10^{\prime}$, Feijó $2 O^{\prime \prime}$; Rondônia - Porto Velho $10^{\prime}$, Guajará-Mirim $3 \sigma^{*}$; Mato Grosso Alto Floresta $15 \sigma^{\prime} 11 \bigcirc$, Denise $10^{\prime} 4 \sigma^{\prime}$, Mato Grosso $20^{\prime}$; Minas Gerais - Caratinga 15 9 , Peçanha $10^{\circ}$, Pirapora $10^{\prime}$; Bahia Gandu $10^{\prime}$, Ilhéus $1 \bigcirc^{\prime}$; Espirito Santo - Colatina $1 \widetilde{O}^{\prime}$; Rio de Janeiro - Nova Iguaçu $2 O^{\pi}$ (CPRR); Pend: Madre de Dios $4 O^{7}$, Loreto $4 O^{7}$ (CPRR); Bolívia: $4 \bigcirc^{7}$ (ORSTOM), Alto Beni $1 \sigma^{5}$ (ORSTOM), Pandos 3 $O^{\prime}$ (CPRR); Equador: Paraiso Escondido $3 O^{\prime} 1$, La Tablada $2 \sigma^{\prime}$, Manabi $2 \sigma^{\prime \prime} 3 \bigcirc$, via Marta Quevedo, Km 98-100 $30^{\prime}, 5 \bigcirc$ (FSP).

\section{Acknowledgments}

To Mrs. Alda Lima Falcāo (CPRR), who kindly loaned us the specimens from Brazil, Peru and Bolivia; Dr. Eduardo A. Gomez Landires of the "Facultad de Medicina, Universidad Católica", Guayaquil, who sent us specimens from the coastal region of Equador.

composição de Pifanomyia Ortiz \& Scorza. Rev Bras. Entomol, 1995 [no prelo].

5. LE PONT F; BARRERA, C.; CACERES, A.L.; GALATI, E.A.B.; JARRA, O; RIOFRIO, A.R.; MOLCHET, J.; ECHEVERRIA, R.; GUDERIAN, R.H. Leishmaniose en Equateur. 6. Note epidemiologique et entomologique sur le foyer de leishmaniose de Zumba. Ann. Soc. Belge Méd. Trop., 74: 43-9, 1994.

6. RODRIGUEZ, M.J.D. LOS Phlebotomus del Ecuador (Diptera, Psychodidade), VI. Nuevas capturas. Descripción de una nueva especie: resumen y distribución geográfica. Rev. Ecuator. Hig. Med. Trop., 13: 75-82, 1956.

7. ROLHF, F.J. \& SOKAL, R.R. Statistical tables. 2a. ed. New York, W.H. Freemann and Company, 1981.

8. SOKAI, R.R. \& ROLHF, F.J. Biometry: the principles and practices of statistics in biology researcb. 2a. ed. New York, Freemann and Company. 1981. p. 179-270.

\title{
Resumo
}

\begin{abstract}
Descreve-se Lutzomyla (Pifanomyia) robusta, sp.n., provável velora de bartonelase e leishmaniose tegumentar, de cooméncia em vales interandinos no Peru $\theta$ Equador e que apresenta estrelta afinidade com $L$. serrana (Damasceno $\theta$ Arouck). A separaçấo de ambas fol possivel, por meio de análise de variáncia de alguns caracteres do macho e apenas um da fémea. Na analise de variancia, foram estudadas populaç̋es de L. serrana da regiäo amazónica do Brasil, Penu e Bolivia; costa do Equador, regiäo atiântica e outras áreas do Brasil. Corrobora-se a sinonimia de Phlebotornus guayasi Rodriguez comL. serrena.
\end{abstract}

Psychodidae, classificação, Ecologia de vetores. 